\title{
TEMPORAL CHANGES OF LAND USE CAPABILITY CLASSIFICATION DEPENDING ON THE URBAN DEVELOPMENT: CASE STUDY OF TRABZON PROVINCE
}

\author{
H. E. Colak ${ }^{a}$, T. Memisoglu ${ }^{\text {a* }}$ \\ ${ }^{a}$ KTU, Dept. of Geomatic Engineering, Karadeniz Technical University, Trabzon, Turkey- (ecolak@ktu.edu.tr, \\ tugbamemisoglu@ktu.edu.tr)
}

KEY WORDS: Land use, land use capability, temporal change, urban development, Trabzon, Turkey

\begin{abstract}
:
Achieving high efficiency by taking advantage of agricultural land at a high level allows the continued vitality of the soil and also contributes to the country's economy. The land with the most fertilizer from agricultural land is generally the first class agricultural land (I.) followed by second (II.) and third class (III.) agricultural lands. It is accepted that all these lands are considered to be protected and various restrictions have been introduced to these lands. Soil conservation, use and development of balanced is possible to be defined in detail by exploiting the developing science and technology possibilities, determination well-defined properties and the implementation of policies by making the necessary plans. For this reason, Trabzon province is selected as the pilot region land use capability of agricultural land classes (especially urban-rural area and plateau) ongoing changes in the past years until today are examined depending on the land use first, second and third class. In this context, satellite images for 2002, 2005, 2009 and 2017 and land use data including the non-agricultural use of the province of Trabzon has been discussed and the temporal changes of agricultural areas depending on land use capability have been examined using Geographic Information Systems (GIS). In all the productive areas of Trabzon Province, the increase in urban-rural development has been examined in detail because of especially the creation of planned areas and the occurrence of construction needs. This study is a small-scale case study and the results are examined and analyzed using GIS.
\end{abstract}

\section{INTRODUCTION}

Agricultural land generally is considered suitable for agriculture in terms of topography and climate characteristics or has been converted into cultivated land areas. Agricultural areas are classified according to their importance by considering certain standards for the purpose of the proper use of agricultural land in agricultural production and to transfer it to other uses. This classification is mainly aimed at preventing the unintended use of agricultural land (T.C. Offical Gazette, 2005; URL-1, 2016). In 2001, the decisions taken in the Turkish Civil Code didn't prevent the disintegration of agricultural land (T. C. Offical Gazette, 2001). For this reason, in Turkey, "Law on Soil Protection and Land Use, Law No:5403" was issued in 2005 (T.C. Offical Gazette, 2005). The purpose of the "Law on Soil Protection and Land Use" determine procedures and principles that provides conservation and development of soils, classification of agricultural land, determination of minimum and sufficient agricultural land sizes and prevention of their division and the planned use of agricultural land and sufficient income agricultural land in accordance with environment priority sustainable development principle (T.C. Offical Gazette, 2005). In this context, it is aimed to protect the soil.

The average between 50 and 100 thousand hectares of land every year in Turkey is exposed to non-agricultural use departing from agricultural production (xxxxx). In particular, in the evaluation of use agricultural areas covering the years 2004-2013 carried out by Turkish Statistical Institute, it has been determined that 27.8 million decares of agricultural land are left out of production in Turkey (TUIK,2016). As long as the agricultural use of the agricultural land areas continues in our country, the limited amount of fertile agricultural land areas will decrease rapidly and destroyed. At this point, at the 2023 target of the Ministry of Development has report of the Working Group on the Sustainable
Use of Agricultural Land. There are some regulatory initiatives in this report about the vision of the future (T.C. Kalkınma Bakanlığ 1 2014) and it is aimed to protect agricultural land areas in our country. In the conducted national studies about land use have been continued and determinations have been carried out (Y1lmaz,2001; Yavuz, 2005; Kayıkç1,2005; Topçu, 2012; Dengiz ve Turan, 2014; Geymen, 2017).

For this study, Trabzon province was selected as pilot region since the geological structure of Trabzon province is not suitable for agriculture, a large part of the land can not be used for cultivation purposes. Especially when important agricultural land areas are located in coastal areas, people search for new habitats which leads to the creating of important agricultural land to construction. The agricultural land class maps of 1996, obtained from the General Directorate of Agricultural Reform shows that important agricultural land areas has more precedence in Trabzon. But lack of alternative areas in recent years and especially the creation of planned land areas cause agricultural land to be used out of agriculture and this has led to a reduction of the existing productive agricultural land areas. On the other hand, in recent years especially in the province of Trabzon, rapid urbanization process and activities and determining the form of land use the creation of planned areas such as industry, tourism in the plateaus has led to an increase in non-agricultural use. However, the result of the use of agricultural land areas for nonagricultural purposes such as urbanization, industry and tourism reveal the danger of extinction so that there is no recycling of agricultural land.

In the province of Trabzon selected as the pilot region in the study, non-agricultural uses in land use capability, creation of new living spaces, the creation of planned lands within economic purposes such as tourism, industry has been carried out. Ministry of Food, Agriculture and Livestock Provincial Directorate of

*Corresponding author 
Trabzon have provided Datas belonging to agricultural land areas. As the spatial data in the execution of the work, earth maps and satellite images of different years are used. Spatial datas of the $1^{\text {st }}, 2^{\text {nd }}$ and $3^{\text {rd }}$ degree agricultural land subject to the study is evaluated using the soil map produced in 1996. The satellite images that temporal changes can be analyzed are provided satellite images from 2002, 2005, 2009, and 2017 located in Google Earth program. In the point of providing the spatial data on the obtained images, digitization were done using Geographic Information Systems and Google Earth program jointly. The amount of increase in the construction was calculated by taking into account the regions where the temporal change is most observed through the spatial data and the size of the progression from the coastal parts of the new settlement to the rural areas and plateau has been examined. Spatiotemporal changes depending on years were examined and current situation at major small locations are examined with as a case study.

\section{MATERIAL AND METHODS}

\subsection{Study area}

This study was carried out in the province of Trabzon, which is one of the largest cities in the eastern Black Sea region of north east Turkey. The province is located between the eastern meridian of $38^{\circ} 30^{\prime}-40^{\circ} 30^{\prime}$ and the northern paralel of $40^{0} 30^{\prime}$ $41^{0} 30$ '. The area selected as the pilot zone is shown in Figure 1.

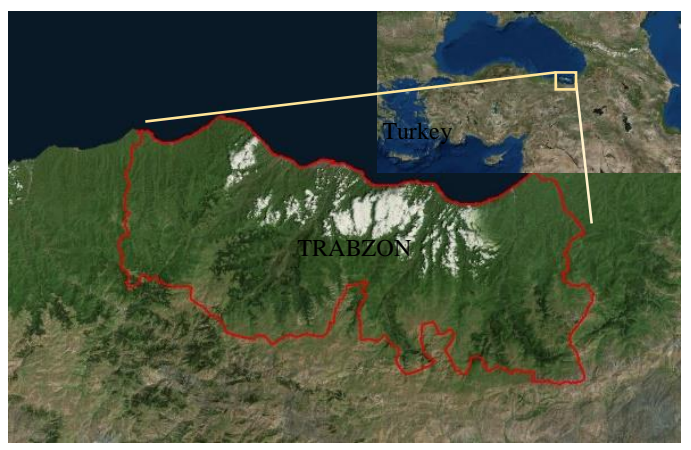

Figure 1. Study area

\subsection{Data acquisition and regulation}

In this study, it was examined the impact of construction on the agricultural lands both urban and rural areas, and also plateau especially in relation to tourism in Trabzon Province. Temporal change analysis were performed using land maps and satellite images. For this purpose, relevant spatial datas were evaluated in ArcGIS 10.4 software. In this context, the land data was provided from the Provincial Directorate of Agriculture of Trabzon in 1996 and satellite images for 2002, 2005, 2009 and 2017 were provided via Google Earth program. First of all, datas on agricultural lands taken from the Provincial Directorate of Agriculture have been arranged. On the spatial data with the help of the map of classes of agricultural lands called land use capability classification map, agricultural lands have been identified and the degrees of these fields have been added to the attribute table (I., II, III.). $1^{\text {st }}, 2^{\text {nd }}$ and $3^{\text {rd }}$ degree agricultural lands were divided into separate layers on the remaining agricultural land using ArcGIS 10.4 software (Figure 2).
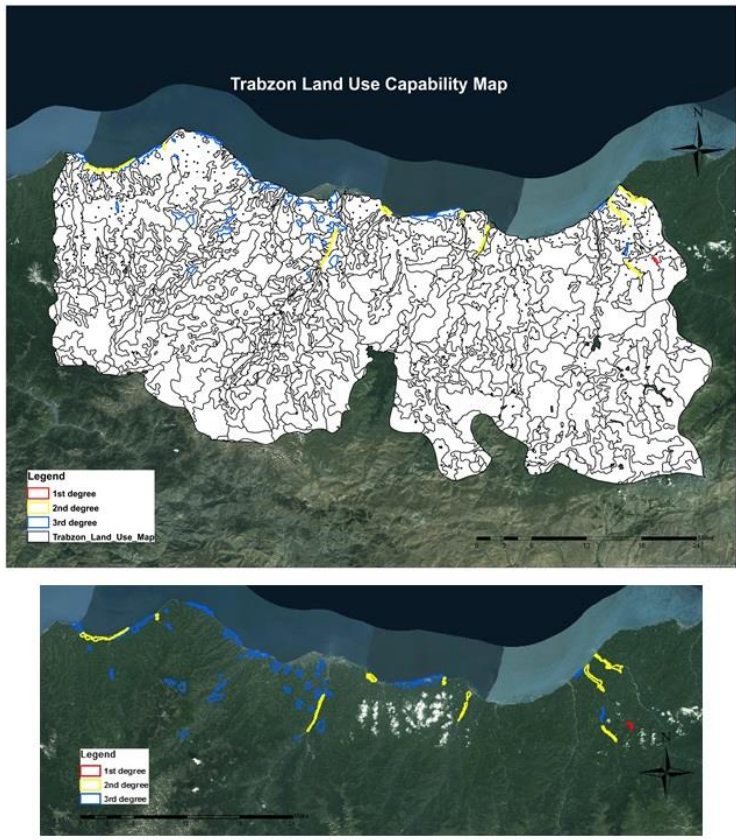

Figure 2. Trabzon land use capability classification map

The surface area of these lands was calculated with the help of the program. In order to determine the extent to which the construction has increased based on the images available in 2002, 2005, 2009 and 2017, the existing spatial datas were transferred to Google Earth and the constructions are digitized using Google Earth and ArcGIS program together. All datas were then integrated into the ArcGIS 10.4 program to create a spatial database. The database of the GIS layer showing the land use capability of Trabzon province was shown in Figure 3. In this context, the locations of the $1^{\text {st }}, 2^{\text {nd }}$ and $3^{\text {rd }}$ degree agricultural land were searched through questionnaires in the related database (Figure 3).

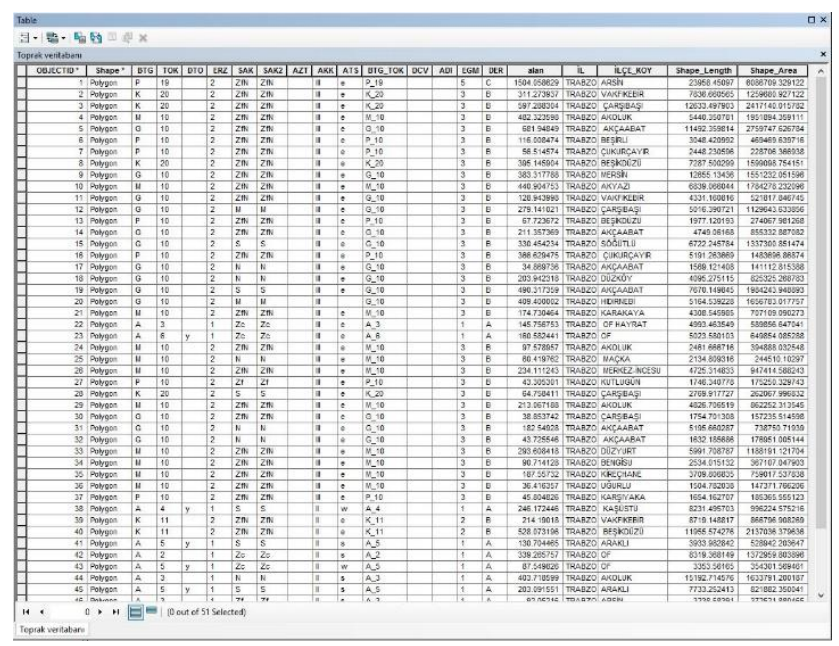

Figure 3. Trabzon land use capability classification database on ArcGIS software

When the data of agricultural land classification of Trabzon province was evaluated, it has been determined that there was only $1^{\text {st }}$ degree of agricultural land. This agricultural land was located Hayrat District in the Province of Trabzon and has of $96.096 \mathrm{~m}^{2}$ surface area. Looking at the $2^{\text {nd }}$ degree agricultural land, 12 agricultural land in Trabzon province has been 
determined. The total surface area of these areas were $3289.29 \mathrm{~m}^{2}$. Some of these lands were close to the city center and coastal parts, while some remain in mountainous areas. Fertile agricultural land areas close to the city center and coastal areas have been almost disappeared exposed to construction as a result of increasing population growth and people needing new places to live. Fertile agricultural land areas located in mountainous areas, there was no improvement in the construction of these areas due to the fact that they were far away from construction. These lands were located in: Ortahisar district Akoluk village, Araklı district Yigitozu village, Arsin district Yanbolu village, Besikdüzü district coastal part, Carsibasi district coastal part, Hayrat district, Ortahisar district Kasüstü town, Of district (4 agricultural land areas), Vakfikebir district. The $3^{\text {rd }}$ degree agricultural land was 36 and the total surface area is $9605.10 \mathrm{~m}^{2}$. While some of these agricultural lands protected its existence by unstructured, agricultural lands were built at high rates and deprived of destruction together with the creation of planned areas near the city center.

Given the $3^{\text {rd }}$ degree of agricultural land, 9 of them in Akcaabat district, 15 of them in Ortahisar district, 3 of them in Vakfikebir district, 1 of them in Macka district, 1 of them in Of District, 1 of them in Arsin district, 2 of them in Besikdüzü district, 1 of them in Duzkoy district, 1 of them in Hayrat district. According to the obtained findings, a total of 49 agricultural lands were found in the form of efficient land classification.

\subsection{Examining of increase in construction on fertile agricultural land}

Considering the current agricultural land in the province of Trabzon, it has been identified 1 in total 1 st degree, 12 in total 2nd degree and 36 in total 3rd degree agricultural land. These were obtained through Google Earth based on the years in which these agricultural land areas are adequate for satellite imagery. The constructions on both of the received satellite images were digitized with the help of Google Earth and ArcGIS 10.4. So, the increase in the constructions and development between years was observed. Since the $1^{\text {st }}$ degree agricultural land was located in the mountainous area, there was no settlement here. It was discussed $2^{\text {nd }}$ and $3^{\text {rd }}$ degree agricultural land that the construction has increased visibly over the years, creation of planned areas and urban change due to the search for new settlements. Accordingly, two $2^{\text {nd }}$ degree agricultural land area, two $3^{\text {rd }}$ degree agricultural land area was carried out. While Arakli and Vakfikebir districts were examined $2^{\text {nd }}$ degree agricultural land areas, Akcaabat district and Hidirnebi plateau were examined $3^{\text {rd }}$ degree agricultural land areas.

\section{RESULTS}

As a result of the application, it was seen that there was no construction in the Hayrat district, which has the $1^{\text {st }}$ degree agricultural land area. When the fields encountering the secondary agricultural land were considered, 2009 and 2017 satellite images were taken as basis for Arakli district. As a result of the digitization process performed in 2009, there were 127 construction buildings in this area and in 2017 the number of construction buildings has increased to 164 . In the 8 years, the number of buildings increased by 37 . Construction was increased by about $29.13 \%$ in this area (Figure 4 ).
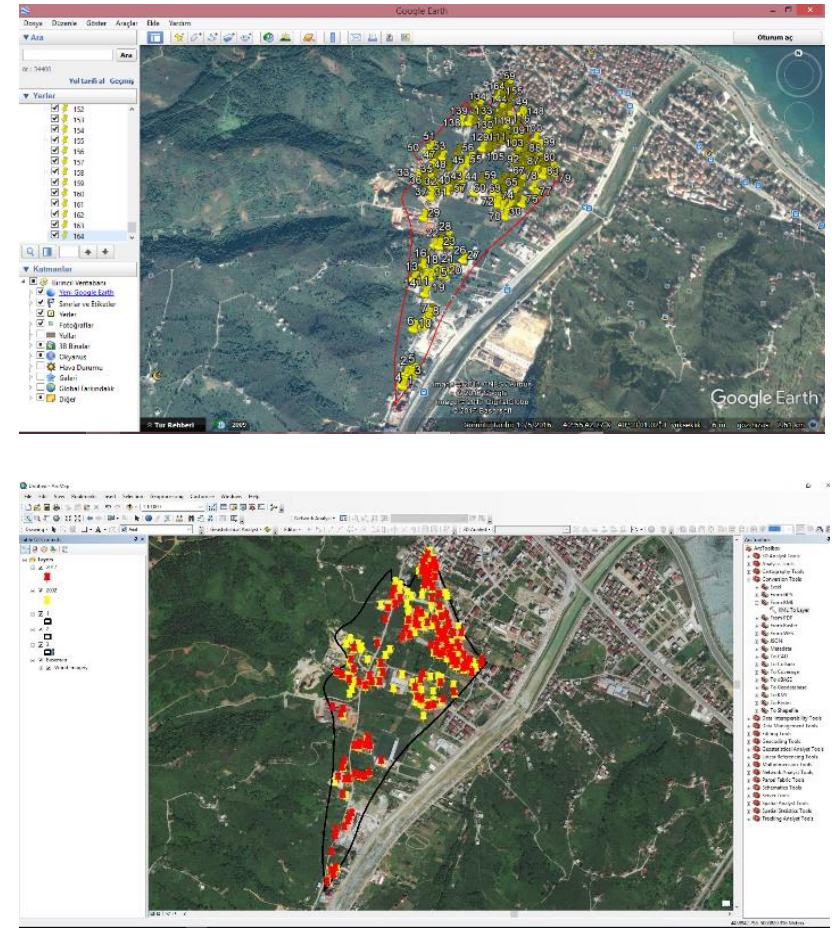

Figure 4. $2^{\text {nd }}$ degree coinciding part of urban development in the Arakli district

2009 and 2017 satellite images were taken as basis for the Vakfikebir district located on the coastal area. As a result of the digitization process performed in 2009, there were 209 construction buildings in this area and in 2017 the number of construction buildings has increased to 222 . In the 8 years, the number of buildings increased by 13 . Construction was increased by about $6.22 \%$ in this area (Figure 5 ).

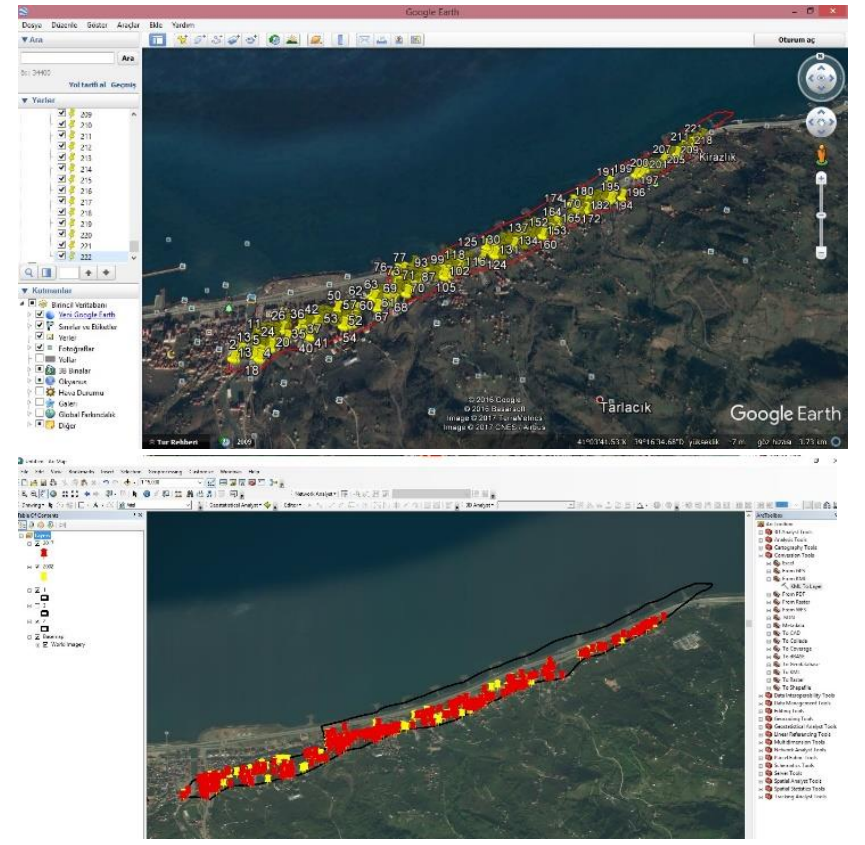

Figure 5. $2^{\text {nd }}$ degree coinciding part of urban development in the Vakfikebir district 
Looking at the $3^{\text {rd }}$ degree areas covered in the application, 2002 and 2017 satellite images were taken as basis located at the center of the Akcaabat district in the coastal area. Because of the digitization process performed in 2002, there were 303 construction buildings in this area and in 2017 the number of construction buildings has increased to 575 . In the 15 years, the number of buildings increased by 272. Construction was increased by about $89.72 \%$ in this area (Figure 6).
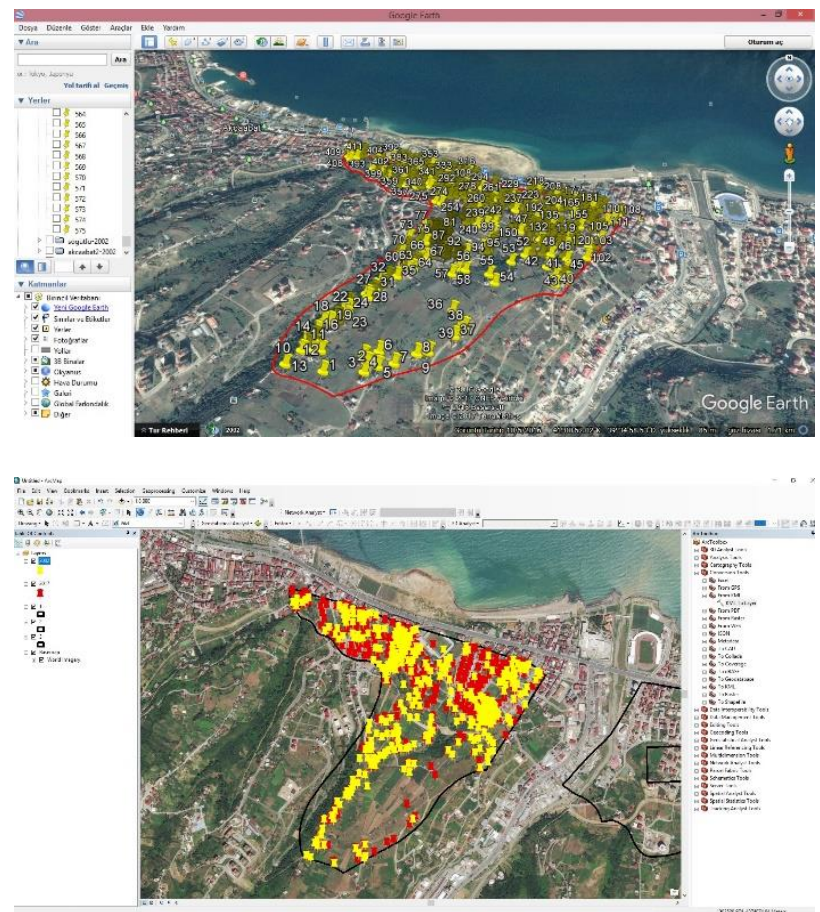

Figure 6. $3^{\text {rd }}$ degree coinciding part of urban development in the Akcaabat district

Another $3^{\text {rd }}$ degree agricultural land, was located on the Hidirnebi plateau, satellite images for 2005 and 2017 were taken as basis. As a result of the digitization process performed in 2005, there were 196 construction buildings in this area and in 2017 the number of construction buildings has increased to 313 . In the 15 years, the number of buildings increased by 117 . Construction was increased by about $59.69 \%$ in this area (Figure 7).

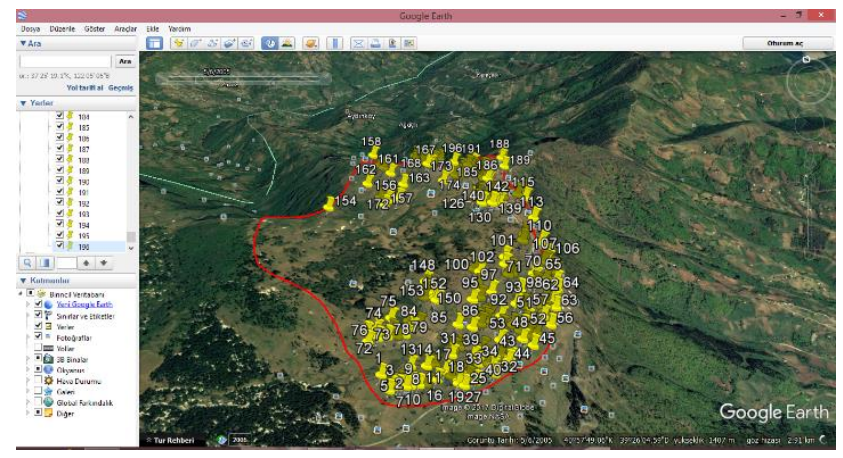

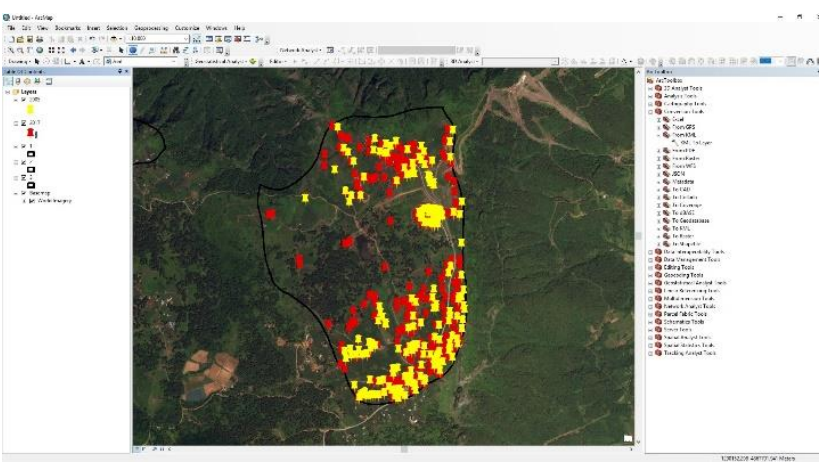

Figure 7. $3^{\text {rd }}$ degree coinciding part of urban development in the Hidirnebi plateau.

\section{CONCLUSION}

Geographical conditions in the province of Trabzon, due to the excessive formation of land slope, inadequacy of suitable alternative areas for settlement and geological structure, land use control is restricted and therefore the agricultural land areas seems to have begun to be built over time. While many parts of agricultural land in mountainous areas are not observed to be constructed, in many agricultural areas close to the city center and the social structure due to the both creating planned area and the increase in population density has improved over the years and the rate of non-agricultural use has increased. This construction seems to be increasing day by day. As a result of further increase in the misuse of agricultural land, this land areas begun to transform ordinary concrete piles. So, the agricultural land has lost its quality over the years. Accordingly, the remaining agricultural land needs to be used and protected effectively.

In this study, the chosen pilot Trabzon province, land use capability classes subject to construction due to urbanization, opening of planned areas and increase in economic investments depending on time and also the changes that took place during the non-agricultural use were examined. This study was a case study, which deals with the development of the settlement, both in urban areas, in rural areas and especially in plateau. In this regard, it has been provided primarily land use map of Trabzon Province. Satellite images were then provided for easy viewing of the area. Land use capability classes of agricultural land have been determined and the areas that were most exposed to construction are discussed. Changes in these areas over time were compared via satellite images and the results were evaluated. As a result of the study, in the Province of Trabzon, it was seen that there was only one region the $1^{\text {st }}$ degree agricultural land areas, this area was located in Hayrat district and there was no construction in this part and the fertile land continues to be used for agricultural purposes. In the $2^{\text {nd }}$ degree agricultural land area of Arakli district, it was monitored that there was partly constructed area and after the year 2009, with the construction of $29 \%$, the period of pressure for the purpose of urbanization in agricultural land. It can be said that only $6 \%$ of the restructured settlements have occurred in the last eight years in Vakfikebir district where was very little construction and with the same quality of agricultural activities. In the $3^{\text {nd }}$ degree agricultural land area of Akcaabat district, it was said that about $90 \%$ of construction, which was the most construction since 2002 and it has been observed that there were almost no areas where agricultural activities have been carried out in the designated lands. Akcaabat district compared to the other provinces is an 
attractive location in the name of urbanization due to the increasing population density, proximity to the provincial center and the possibility of public investments. Because of this, it was observed that the $3^{\text {rd }}$ degree agricultural land was transformed into construction. In the $3^{\text {nd }}$ degree agricultural land area of Hidirnebi plateau located in the town of Akcaabat, a build-up of approximately $60 \%$ has been observed since 2005 . In addition to tourism-oriented businesses, rapid urbanization in this region was concerned because the people of the region have built houses for summer. As the plateau starts to build up in an unplanned and uncontrolled manner, the already limited agricultural land has been faced with the pressure to build up. Areas like a plateau for the use of the animal for animal activities so that exposure to construction and non-purpose plateau use, it will confront as a threat factor for tourism activities at the same time in the coming years.

With this study, it is aimed to show the oppression that the arable land is exposed to because of the construction. As a result of the evaluations performed by analysis, development of policies for agricultural land and it was observed that in practice every new area opened to the plan gave rise to settlement pressures in the immediate vicinity. In addition, when the provinces of Akcaabat and Vakfikebir are compared, the speed up to $90 \%$ of the construction in Akcaabat district, which is very close to the provincial center, poses a big threat in agricultural areas close to the city center. Therefore, policies to be applied to agricultural land should be rearranged so as not to adversely affect the environment. At the same time, the Turkish Statistical Institute should keep statistics on non-agricultural use of agricultural land regularly. National Soil Database should be created by using current methodologies of methods such as Remote Sensing and Geographic Information Systems.

\section{REFERENCES}

Dengiz, O., Turan, İ. D., 2014. Uzaktan Algılama ve Coğrafi Bilgi Sistem Teknikleri Kullanılarak Arazi Örtüsü / Arazi Kullanımı Zamansal DeğiGimin Belirlenmesi: Samsun Merkez Ġlçesi Örneği (1984-2011), Türkiye Tarımsal Araştırmalar Dergisi, Turkish Journal of Agricultural Research, 1(1): 78-90.

Geymen, A., 2017. Coğrafi Bilgi Sistemi Kullanılarak Su Havzalarındaki Arazi Kullanım Değişikliği ve Çevresel Etkilerin İzlenmesi: Elmalı Havzası Örneği, Iğdır Üni. Fen Bilimleri Enst. Der. / Iğdır Univ., J. Inst. Sci. \& Tech., 7(1): 171-181.

Kayıkçı, M., 2005. Türkiye'de Tarım Topraklarının Tarım Dışı Amaçlarla Kullanımı - Adapazarı Örneği, Sosyal Araştırmalar Vakf1, İstanbul, ss.40-94-148-171-179

RESMI GAZETE (Başbakanlık Mevzuatı Geliştirme ve Yayın Genel Müdürlügü), Arşiv-Fihrist-Düstur, Resmi Gazete Tarihi:19.07.2005, 5403 Say1lı Toprak Koruma ve Arazi Kullanım Kanunu. http://rega.basbakanlik.gov.tr

RESMİ GAZETE (Başbakanlık Mevzuatı Geliştirme ve Yayın Genel Müdürlüğü), Arşiv-Fihrist-Düstur, Resmi Gazete Tarihi: 08.12.2001, 4721 Sayılı Türk Medeni Kanunu. http://rega.basbakanlik.gov.tr

TUIK,2016.https://biruni.tuik.gov.tr/bolgeselistatistik/tabloYilS utunGetir.do?durum=acKapa\&menuNo=191\&altMenuGoster $=1$ Topçu, P., 2012. Tarım arazilerinin korunması ve etkin kullanılmasına yönelik politikalar, Yayın No:2836, Uzmanlık tezi, T. C. Kalkınma Bakanlığı, İktisadi Sektörler ve Koordinasyon Genel Müdürlüğü, Mart, Ankara.
T.C.Kalkınma Bakanlığı, 2014. Tarim arazilerinin sürdürülebilir kullanimi çalişma grubu raporu, Tarim özel ihtisas komisyonu, Onuncu Kalkınma Planı 2014-2018, Ankara.

URL-1,

2016.http://www.tarim.gov.tr/Belgeler/Mevzuat/Talimatlar/Top rakAraziSiniflamasiStandartlariTeknikTalimativeIlgiliMevzuat_ yeni.pdf

Yavuz, F., 2005. Türkiye'de Tarım, Tarım ve Köyișleri Bakanlığı, Aralık, Erzurum, http://www.tarim.gov.tr/SGB/Belgeler/yayinlar/turkiyede_tarim .pdf

Yılmaz, Ö.,2001. Tarım Alanlarının Amaç Dışı Kullanımı ve Afyon Örneği, Afyon Kocatepe Üniversitesi Sosyal Bilimler Dergisi,Cilt II, Say1:2, Afyon, ss. 161-162. 